\title{
Effect of calcium channel blockers on the serum levels of thyroid hormone
}

\author{
Rimple J. Kaur ${ }^{1 *}$, Bharati Mehta ${ }^{2}$, Sneha R. Ambwani ${ }^{3}$, Anusuya Gehlot ${ }^{1}$
}

${ }^{1}$ Department of Pharmacology, Dr. S.N. Medical College, Jodhpur, Rajasthan, India

${ }^{2}$ Department of Physiology and ${ }^{3}$ Department of Pharmacology, All India Institute of Medical Sciences (AIIMS), Jodhpur, Rajasthan, India

Received: 5 July 2013

Accepted: 7 July 2013

*Correspondence to: Dr. Rimple J. Kaur,

Email:

sidhurimple@yahoo.com

(C) 2013 Kaur RJ et al. This is an open-access article distributed under the terms of the Creative Commons Attribution License, which permits unrestricted use, distribution, and reproduction in any medium, provided the original work is properly cited.

\begin{abstract}
Background: The effect of the calcium channel blockers on the cardiovascular system is implemented judiciously in different conditions related to cardiovascular system such as angina pectoris, hypertension, and in cardiac arrhythmias but the aspect that deals with the impact of blockade of calcium channels in other systems like endocrine system remains eclipsed. These effects generally go unnoticed and the present study was formulated to elucidate the serum $\mathrm{T}_{3}, \mathrm{~T}_{4}, \mathrm{TSH}$ levels after administration of calcium channel blockers and to observe the resultant side effect on the endocrine glands, if any by this commonly used group of drugs.

Methods: The study was conducted on male albino rabbits, they were divided in three groups of ten each and each group received one of the calcium channel blockers- Verapamil, Diltiazem and Nifedipine for three months. At the end of each month the serum $\mathrm{T}_{3}, \mathrm{~T}_{4}$, TSH levels were evaluated by chemiluminisence.

Results: It was found that on continuous daily administration of calcium channel blockers there was a gradual fall in levels of $\mathrm{T}_{3}$ and $\mathrm{T}_{4}$ with rise in TSH levels in comparison to the control value taken before initiating the drug therapy.

Conclusion: These findings could have potential clinical implications and this study proposes the importance of blood thyroid hormone level follow up in the long-term calcium channel blocker therapy.
\end{abstract}

Keywords: Calcium channel blockers, Thyroid gland, $\mathrm{T}_{3}, \mathrm{~T}_{4}, \mathrm{TSH}$

\section{INTRODUCTION}

The calcium ions play an important role in many biological processes and the calcium channels which are present in almost all the body system and organs including cardiovascular system regulate the entry of calcium in cell.

It is a well-established fact that calcium plays an important role in the synthesis, release and functions of several hormones. ${ }^{1}$ In past years, interactions between cations and secretagogeous, in the process of hormone release have been studied by examining the effects of various organic calcium antagonists upon isolated secretory tissues. ${ }^{2}$ The effects of these agents are overcome by increased concentration of extracellular calcium. Because of high activity and apparent selection of these agents, their activity in other systems can be viewed as evidence that basically slow calcium channels are operative in variety of secretory processes. ${ }^{3,4}$ Thus the administration of calcium channels blockers (CCBs) may affect these hormones at some level. Although, it is difficult to delineate the exact mechanism of these drugs, but as the name itself suggests that the CCBs act by blocking the calcium channels thus altering the calcium concentration inside the cells. They inhibit the entry of calcium through these channels in those tissues in which depolarization is dependent on calcium rather than on sodium influx; these include vascular smooth muscles, myocardial cells and cells of sino atrial and atrioventricular nodes. ${ }^{5}$

Several reports are available to justify the action of CCBs on hormones. Studies in vivo showed that, verapamil 
inhibited the endogenous TRH (thyroid releasing hormone) synthesis with a subsequent decrease in TSH (thyroid stimulating hormone) stored or alternatively it may alter in some way the intracellular stores of calcium which prevented TSH release from the thyrotropes ${ }^{6}$ and stimulation of TSH beta gene transcription requires calcium release from inositol triphosphate sensitive stores and calcium ion influx via $L$ type calcium channel. ${ }^{7}$

Studies on the effect of calcium channel activator BAYK-8644 on invitro secretion of calcitonin and parathyroid hormone indicated that calcium entry into the thyroid $\mathrm{C}$ cell and parathyroid chief cell may occur via classical voltage sensitive calcium channels and the calcium activator BAY-K-8644 should prove useful for studying hormone secretion in calcium dependent secretory systems. ${ }^{8}$

It was observed that cytoplasmic calcium derived from the extracellular and intracellular sources plays a pivotal role in controlling TRH-stimulated $\mathrm{TSH}$ secretion in human subjects. ${ }^{9}$

These observations suggest that the CCBs have effect on the serum levels of certain hormones by interfering with their synthesis, release or function.

Thus, this study has been undertaken to elucidate effect of CCBs on serum thyroid hormones e.g. triiodothyronine $\left(\mathrm{T}_{3}\right)$, tetra-iodothyronine or thyroxine $\left(\mathrm{T}_{4}\right)$ and thyroid stimulating hormone (TSH), and to observe the resultant side effects of any of these commonly used drugs.

\section{METHODS}

This study was conducted in the Department of Pharmacology, Dr. Sampurnanand Medical College,
Jodhpur after acquiring the approval from Animal Ethics Committee (Registration number 692/02/a/CPCSEA). These rabbits were divided into three groups with ten rabbits in each group. Male Albino rabbits (1.5 to 2.5 $\mathrm{kgs}$ ) were used. These rabbits were divided into three groups with ten rabbits in each group.

Group I: Received verapamil orally, in a dose of 9.6 $\mathrm{mg} / \mathrm{kg} /$ day.

Group II: Received diltiazem orally, in a dose of $4.8 \mathrm{mg} / \mathrm{kg} / \mathrm{day}$.

Group III: Received nifedipine orally, in a dose of 1.2 $\mathrm{mg} / \mathrm{kg} /$ day.

Blood sample was obtained from ear vein of the rabbits of all the three groups and then the serum was separated for the estimation of levels of thyroid hormones $\left(T_{3}, T_{4}\right.$ and TSH) prior to drug therapy. These levels served as control value. Thereafter, drug therapy was started and continued for three months and at the end of each month the serum levels of these hormones were again estimated and compared with the previous values. The serum hormonal levels of rabbits of all three groups were evaluated by chemiluminisence using ADVIA Centaur system, which is an automated immunoassay analyzer. Throughout the study, animals were housed in the departmental animal house at the room temperature of $25^{\circ} \mathrm{C}$ to $30^{\circ} \mathrm{C}$ with food and water ad lib.

\section{RESULTS}

The serum levels of hormones were estimated after the end of one month's therapy and compared with control levels. It was observed that all the three CCBs i.e. Verapamil, Diltiazem and Nifedipine cause fall in the serum levels of $\mathrm{T}_{3}, \mathrm{~T}_{4}$ and rise in $\mathrm{TSH}$ level. At the end of second and third month, further fall in serum levels of $\mathrm{T}_{3}$ and $\mathrm{T}_{4}$ and rise in TSH level were observed (Table 1, 2 and 3 ).

Table 1: Effect of different $\mathrm{CCB}_{\mathrm{S}}$ on serum $\mathrm{T}_{3}$ level. $(\mathrm{Mean} \pm \mathrm{SEM})$ in $\mathrm{ng} / \mathrm{dl}$.

\begin{tabular}{|c|c|c|c|c|c|}
\hline S. No. & Drugs & Control & After one month & $\begin{array}{l}\text { After two } \\
\text { months }\end{array}$ & $\begin{array}{l}\text { After three } \\
\text { months }\end{array}$ \\
\hline \multirow{2}{*}{1.} & \multirow{2}{*}{ Verapamil } & \multirow{2}{*}{$0.228 \pm 0.029$} & $0.184 \pm 0.025$ & $0.145 \pm 0.021$ & $0.102 \pm 0.051$ \\
\hline & & & $\mathrm{P}<0.05$ & $\mathrm{P}<0.01$ & $\mathrm{P}<0.01$ \\
\hline \multirow{2}{*}{2.} & \multirow{2}{*}{ Diltiazem } & \multirow{2}{*}{$0.254 \pm 0.027$} & $0.226 \pm 0.024$ & $0.190 \pm 0.022$ & $0.153 \pm 0.018$ \\
\hline & & & $\mathrm{P}<0.01$ & $\mathrm{P}<0.01$ & $P<0.01$ \\
\hline \multirow{2}{*}{3.} & \multirow{2}{*}{ Nifedipine } & \multirow{2}{*}{$0.283 \pm 0.030$} & $0.254 \pm 0.027$ & $0.197 \pm 0.024$ & $0.143 \pm 0.018$ \\
\hline & & & $\mathrm{P}<0.01$ & $\mathrm{P}<0.01$ & $\mathrm{P}<0.01$ \\
\hline
\end{tabular}

$\mathrm{p}=$ line of significance: $\mathrm{p}<0.01$ statistically significant as compared to control group. 
Table 2: Effect of different $\mathrm{CCB}_{\mathrm{S}}$ on serum $\mathrm{T}_{4}$ level. $(M e a n \pm S E M)$ in $\mu \mathrm{g} / \mathrm{dl}$.

\begin{tabular}{|c|c|c|c|c|c|}
\hline S. No. & Drugs & Control & After one month & $\begin{array}{l}\text { After two } \\
\text { months }\end{array}$ & $\begin{array}{l}\text { After three } \\
\text { months }\end{array}$ \\
\hline \multirow{2}{*}{1.} & \multirow{2}{*}{ Verapamil } & \multirow{2}{*}{$1.846 \pm 0.24$} & $1.817 \pm 0.24$ & $1.765 \pm 0.23$ & $1.646 \pm 0.23$ \\
\hline & & & $\mathrm{P}<0.01$ & $\mathrm{P}<0.01$ & $\mathrm{P}<0.01$ \\
\hline \multirow{2}{*}{2.} & \multirow{2}{*}{ Diltiazem } & \multirow{2}{*}{$1.672 \pm 0.18$} & $1.596 \pm 0.18$ & $1.486 \pm 0.17$ & $1.337 \pm 0.17$ \\
\hline & & & $\mathrm{P}<0.01$ & $\mathrm{P}<0.01$ & $\mathrm{P}<0.01$ \\
\hline \multirow{2}{*}{3.} & \multirow{2}{*}{ Nifedipine } & \multirow{2}{*}{$1.920 \pm 0.21$} & $1.829 \pm 0.21$ & $1.733 \pm 0.20$ & $1.641 \pm 0.20$ \\
\hline & & & $\mathrm{P}<0.01$ & $\mathrm{P}<0.01$ & $\mathrm{P}<0.01$ \\
\hline
\end{tabular}

$\mathrm{p}=$ line of significance: $\mathrm{p}<0.01$ statistically significant as compared to control group.

Table 3: Effect of different $\mathrm{CCB}_{\mathrm{S}}$ on serum TSH level. (Mean $\left.\pm \mathrm{SEM}\right)$ in micro U/L.

\begin{tabular}{|c|c|c|c|c|c|}
\hline S. No. & Drugs & Control & $\begin{array}{l}\text { After one } \\
\text { Month }\end{array}$ & $\begin{array}{l}\text { After two } \\
\text { Months }\end{array}$ & $\begin{array}{l}\text { After three } \\
\text { Months }\end{array}$ \\
\hline \multirow{2}{*}{1.} & \multirow{2}{*}{ Verapamil } & \multirow{2}{*}{$0.429 \pm 0.030$} & $0.476 \pm 0.039$ & $0.546 \pm 0.039$ & $0.609 \pm 0.037$ \\
\hline & & & $\mathrm{P}<0.01$ & $\mathrm{P}<0.01$ & $\mathrm{P}<0.01$ \\
\hline \multirow{2}{*}{2.} & \multirow{2}{*}{ Diltiazem } & \multirow{2}{*}{$0.421 \pm 0.031$} & $0.488 \pm 0.030$ & $0.559 \pm 0.030$ & $0.654 \pm 0.034$ \\
\hline & & & $\mathrm{P}<0.01$ & $\mathrm{P}<0.01$ & $\mathrm{P}<0.01$ \\
\hline \multirow{2}{*}{3.} & \multirow{2}{*}{ Nifedipine } & \multirow{2}{*}{$0.373 \pm 0.027$} & $0.425 \pm 0.026$ & $0.499 \pm 0.022$ & $0.586 \pm 0.022$ \\
\hline & & & $\mathrm{P}<0.01$ & $\mathrm{P}<0.01$ & $\mathrm{P}<0.01$ \\
\hline
\end{tabular}

$\mathrm{p}=$ line of significance: $\mathrm{p}<0.01$ statistically significant as compared to control group.

\section{DISCUSSION}

CCBs are used very widely in day-to-day practice and there are some scattered evidences that these agents might be affecting endocrinal physiology. ${ }^{10}$ Several CCBs are known to affect serum levels of triiodothyronine, thyroxine and thyroid stimulating hormone. ${ }^{11}$ Some studies showed low serum levels of triiodothyronine and thyroxine in some patients receiving CCBs namely -Verapamil, Nifedipine and Diltiazem. ${ }^{12}$ Our study also suggests that CCBs- Verapamil, Diltiazem and Nifedipine decrease the serum levels of $\mathrm{T}_{3}, \mathrm{~T}_{4}$ and increase in TSH levels.

The main clinical use of CCBs is in the management of various cardiovascular diseases e.g. angina pectoris, hypertension, cardiac arrhythmias etc. On the basis of the observations of the present study, it is clear that on longterm calcium channel blocker therapy the functioning of endocrine system is disrupted. Following could be the possible mechanism for these changes:

- Due to interference with the synthesis and release of hormone.

- Due to alteration in the regulatory process of these hormones.

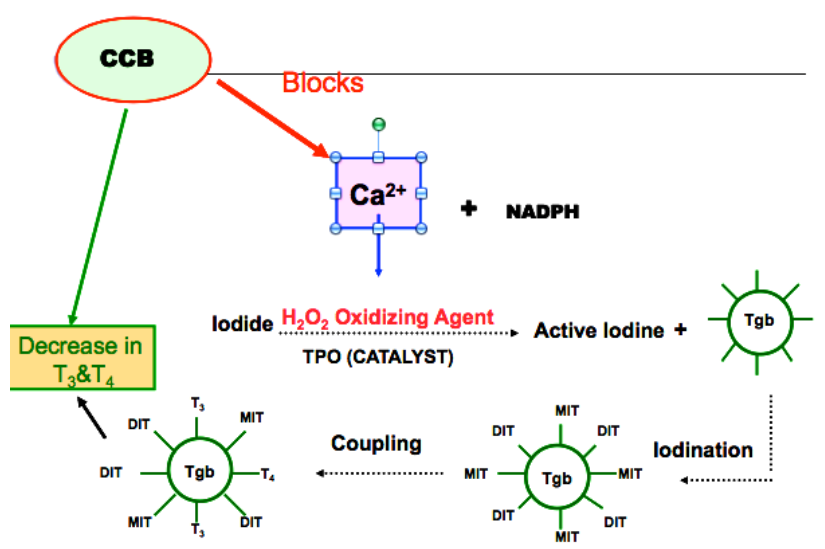

Figure 1: Effect of calcium channel blockers on $T_{3}$ and $T_{4}$ synthesis.

Calcium ions are known to play an important role in the synthesis of thyroid hormones. In the process of thyroid hormone formation after concentrating iodine, the thyroid rapidly oxidizes it and binds it to the tyrosyl residues in the thyroglobulin (TG), followed by coupling of iodotyrosine to form $\mathrm{T}_{3}$ and $\mathrm{T}_{4}$. This process requires iodine, a thyroid peroxidase supply of $\mathrm{H}_{2} \mathrm{O}_{2}$ and an iodine acceptor protein TG. The $\mathrm{H}_{2} \mathrm{O}_{2}$ required for oxidative functions and iodide organification is produced at the apical plasma membrane and there are reports that $\mathrm{H}_{2} \mathrm{O}_{2}$ requires calcium. The production of hydrogen peroxide as an essential process for iodine organification is a key reaction in TSH-induced thyroid hormone synthesis. There is evidence that Thyrotropin-induced $\mathrm{H}_{2} \mathrm{O}_{2}$ 
production in thyroid cells is mediated not by cAMP, but by $\mathrm{Ca}^{++}$signaling followed by phospholipase- $\mathrm{A}_{2}$ activation. ${ }^{13}$ Thus there is possibility that when CCBs are administered for long term therapy, by blocking calcium channels, they reduce the concentration and hence $\mathrm{H}_{2} \mathrm{O}_{2}$ production resulting in reduced synthesis of $\mathrm{T}_{3}$ and $\mathrm{T}_{4}$ (Figure 1). The increase in TSH level is a result of regulatory feedback mechanism. As $\mathrm{T}_{3}$ and $\mathrm{T}_{4}$ levels falls due to $\mathrm{CCB}$, the TRH stimulates the anterior pituitary to produce more TSH that results in elevated blood serum levels.

\section{CONCLUSION}

It is clear that calcium channels are widely distributed in our body system including endocrine system. So when CCBs are used for long term therapy for some other clinical conditions, they may have affect the functioning of endocrine glands at all steps e.g. synthesis, secretion, release and regulation of thyroid hormone. Although the physiology of the rabbits may be different than that of human beings, but the clinical observation of this study could propose the importance of measurement of thyroid hormone levels, when long term CCBs medication is given.

\section{ACKNOWLEDGEMENTS}

The authors gratefully acknowledge the guidance and support provided throughout this entire research work by Dr. Adesh K Mathur, former Professor and Head, Department of Pharmacology, Dr. S.N. Medical College, Jodhpur India.

\section{Funding: None}

Conflict of Interest: None declared

Ethical approval: The study was approved by the Institutional Animal Ethics Committee

\section{REFERENCES}

1. Douglas WW, Rubin RP. Mechanism of catecholamine release from the adrenal medulla and the role of calcium in stimulation secretion coupling. J Physiol (Lond.) 1963;167:288.

2. Ikeda K, Isaka T, Fujioka K, Manome Y, Tojo K. Suppression of aldosterone synthesis and secretion by $\mathrm{ca}^{2+}$ ) channel antagonists. Int $\mathrm{J}$ Endocrinol. 2012;2012:519467.

3. Eto S, McMillan Wood J, Hutchins $M$. and Flesischer N. Pituitary calcium uptake and release of ACTH, GH and TSH: effect of verapamil. Am J physiol. 1974;226:1315.

4. Dreifus JJ and Gran JD. Effects on the isolated neurohypophysis of agents that affect the membrane permeability of calcium. J Physiol 1973;231:96.

5. Elliott WJ, Ram CV. Calcium channel blockers. J Clin Hypertens (Greenwich). 2011 Sep;13(9):687-9.

6. Barbarino A and Marinis LD. Calcium antagonists and hormone release II. Effects of verapamil on Basal Gonadotrophins Releasing Hormone and thyrotropin releasing hormone. Induced pituitary release in normal Subjects. J Clin Endocrino \& Metob 1980;749:51-4.

7. Shupnik MA, Weck J and Hinkle PM. Thyrotropin (TSH) releasing hormone stimulates TSH beta promoter activity by two distinct mechanisms involving calcium influx through type $\mathrm{Ca} 2+$ channels and protein kinase C. Mol Endocrino. 1996;10(1): 90-9.

8. Cooper CW, Borosky SA, Farrell PE and Steinsland OS. Effects of the calcium channel activator Bay-K 8644 on in vitro secretion of calcitonin \& parathyroid hormone. Endocrinol 1986;118:545-9.

9. Yamada M, Mori M, Yamaguchi M, Akiyama H, Shiono S, Kobayashi I, Kobayashi S. Thyrotropinreleasing hormone stimulation of thyrotropin secretion is suppressed by calcium ion antagonists that block transmembrane influx and intracellular mobilization of calcium ion in human subjects. J Endocrinol Invest. 1986 Jun;9(3):227-31.

10. Turnbull FM, Woodward M. Calcium antagonists revisited. J Hypertens 2009;27(6):1121-2.

11. Wartofsky L, Ingbar SH. Diseases of thyroid. In: Harrison's Principles of Internal Medicine, New York: McGraw Hill, 1991;1692-1712.

12. Mittal SR, Mathur AK, Prasad N. Effect of calcium channel blockers on serum levels of thyroid hormones. Int J Cardiol 1993;38:131-2.

13. Kimura T, Okajima F, Sho K, Kobayashi I, Kondo Y. Thyrotropin-induced $\mathrm{H} 2 \mathrm{O} 2$ production in FRTL5 thyroid cells is mediated not by cAMP, but by $\mathrm{Ca}++$ signaling followed by phospholipase-A2 activation and potentiated by adenosine derivative. Endocrinology. 1995 Jan;136(1):116-23.

doi:10.5455/2319-2003.ijbcp20130824

Cite this article as: Kaur RJ, Mehta B, Ambwani SR, Gehlot A. Effect of calcium channel blockers on the serum levels of thyroid hormone. Int J Basic Clin Pharmacol 2013;2:476-9. 